\title{
Persepsi Intonasi Tuturan Kaum Bangsawan Melayu Terhadap Emosi (Perception of the Speech Intonation of the Malay Nobility Against Emotions)
}

Emmy Erwina ${ }^{a, 1}$

aUniversitas Harapan Medan, Indonesia

lemmyerwina8@gmail.com

\begin{tabular}{ll}
\hline Article info & A B S T R A C T \\
\hline Article history: & This study aims to describe the intonation perception of the Malay \\
Revised: $21-03-2021$ & aristocrats' speech on emotions. This study uses an experimental \\
Accepted: 12-04-2021 & phonetic study among the nobility in Tanjungpura, Langkat \\
& Regency, North Sumatra. This study uses acoustic-phonetic theory \\
& and also uses the Praat program. Data analysis used the Average \\
& method so that the percentage of Malay nobility's perception of \\
& the intonation of emotional speech was obtained. The results of \\
& this study get the percentage of data on angry emotional speech, \\
& which is $40 \%$. For the percentage of data on the perception of the \\
& nobility towards sad emotional speech, namely all respondents.
\end{tabular}

Keywords: intonation perception, emotional speech nobility Malays,

Penelitian ini bertujuan untuk mendeskripsikan persepsi intonasi tuturan kaum bangsawan Melayu terhadap emosi. Penelitian ini menggunakan kajian fonetik eksperimental pada kalangan bangsawan di Tanjungpura, Kabupaten Langkat, Sumatera Utara. Penelitian ini menggunakan teori fonetik akustik serta digunakan juga program Praat. Analisis data menggunakan metode Average sehingga diperoleh persentase persepsi kaum bangsawan Melayu terhadap intonasi tuturan emosi. Hasil dari penelitian ini mendapatkan persentase data terhadap tuturan emosi marah, yaitu sebesar $40 \%$. Untuk persentase data persepsi kaum bangsawan terhadap tuturan emosi sedih yaitu seluruh responden.

Copyright (C) 2021 Institut Agama Islam Negeri Syekh Nurjati Cirebon. All rights reserved.

\section{PENDAHULUAN}

Cara bertutur, menulis, serta isyarat adalah cara berkomunikasi pada suatu masyarakat bahasa. Dalam bertutur, ada dua faktor yang relevan, yaitu yang dikatakan atau semantik dan cara sesuatu dikatakan atau prosidi (Defren et al, 2018). Keduanya saling terpisah, tetapi terlibat dalam interaksi yang kompleks. Faktor semantik maupun faktor prosidi sangat memengaruhi persepsi tuturan emosi. Emosi penutur secara tidak langsung dapat diketahui melalui salah satu bentuk cara bertutur, yakni cara bertutur ekspresif (Prasetyo, 2018). Cara bertutur mengekspresikan perasaan penutur kepada mitra penutur. Tuturan berhubungan dengan bunyi bahasa serta berkaitan dengan fonetik (Cahyono, 2016). Studi tentang ilmu fonetik banyak ditemukan dalam berbagai disiplin ilmu karena memiliki hubungan dengan suara apa pun yang dihasilkan dari teks ke ucapan atau dari ucapan ke teks (Mohamed et al, 2020).

Penelitian fonetik terbagi menjadi tiga sub bab, yaitu penelitian sistem yang dapat menghasilkan sebuah bunyi bahasa, sedangkan fonetik artikulatori yang 
menghasilkan bunyi. Penelitian mengenai gelombang bunyi yang dihasilkan dari ucapan melalui udara dapat disebut fonetik akustik (Prihartono, 2018). Penelitian mengenai pendengaran gelombang bunyi bahasa serta alat pendengaran seperti telinga, yaitu fonetik auditori. Fonetik akustik digunakan untuk mencari struktur gelombang bunyi yang muncul dari tuturan seseorang (Rois, 2020). Fonetik auditori sangat subjektif karena banyak dipengaruhi oleh pendengar yang mendengarkan bunyi tersebut (Senen, 2018).

Penelitian terhadap penelitian tuturan emosi telah banyak diteliti dalam kajian psikologi, filsafat, serta antropologi (Poegoeh \& Hamidah, 2016). Padahal, tuturan emosi umumnya berasal dari tuturan bahasa perlu dilihat dari aspek frekuensi, intonasi, dan durasi ujaran dari penutur. Pada saat seorang penutur emosi, tentu terdapat perbedaan frekuensi, durasi, dan intonasi ujarannya dengan yang tidak sedang emosi. Setiap unsur bahasa, tentu mempunyai unsur emosi yang berkaitan dengan tuturan penuturnya, seperti emosi marah, senang, dan sedih, tidak terkecuali bahasa Melayu. Bahasa Melayu yang digunakan di Sumatera Utara tepatnya di daerah Langkat, berfungsi sebagai alat komunikasi, lambang identitas, pendukung kebudayaan masyarakat Melayu. Tiga fungsi tersebut ada dalam kegiatan Kaum Bangsawan Melayu (Nasir \& Hamzah, 2014).

Durasi merupakan hal yang harus diukur dengan sebuah segmen pada satuan milidetik (Jamil, 2017). Jika segmen berbentuk kalimat, perbedaan waktu bisa disebut dengan tempo. Jenis tuturan bahasa Melayu pada emosi dasar berfungsi sebagai ungkapan emosional: 1) emosi marah, merupakan suasana hati untuk mencerca seseorang, 2) emosi sedih, merupakan perasaan yang mendorong yang menyebabkan orang itu menangis atau sedih, dan 3) emosi senang, merupakan suatu perasaan yang menyebabkan orang itu tertawa atau bahagia. Persepsi terhadap emosi perlu dilakukan penelitian melalui intonasi serta durasi tuturannya.

Penelitian ini dipilih didasarkan atas asumsi bahwa terdapat perbedaan emosi kaum bangsawan Melayu ketika berinteraksi dalam kehidupan sehari-hari. Ekspresi emosi dalam bahasa Melayu direalisasikan juga oleh penutur melalui unsur suprasegmental. Suprasegmental merupakan sesuatu yang menyertai bunyi fonem yang bisa berupa tekanan suara, panjang-pendek atau pitch, dan getaran suara, tekanan, nada, jeda serta durasi yang menunjukkan emosi tertentu (Oktavia, 2018). Astuti (2018) dalam penelitiannya mengungkapkan faktor penyebab persepsi tindak tutur ekspresif marah penutur suku Betawi yaitu ketika 'diminta/disuruh' melakukan sesuatu oleh orang lain. Penelitian tindak tutur juga dilakukan oleh Ganie (2014) yang menyatakan intonasi kesantunan terhadap dua tuturan kalimat direktif dan deklinasi memiliki parameter nada yang berbeda, penutur remaja bernada tinggi sedangkan penutur yang sudah dewasa lebih bernada rendah.

Dalam masyarakat kaum bangsawan, pola pendidikan orang tua dipengaruhi oleh kerabat yang memandang pola itu terbaik dan harus dilestarikan, karena pola asuh dilakukan oleh para kaum bangsawan, maka hal yang diajarkan oleh pihak yang lebih tua merupakan sebuah yang baik, baik itu dari segi bahasa, adat istiadat, maupun tata krama yang digunakan (Dewi \&Sukidjo, 2014). Kaum bangsawan dan non-bangsawan dapat memiliki pendidikan yang sama sehingga dapat mempunyai kecerdasan yang sama serta kesempatan yang sama dalam hal memegang jabatan pemerintahan (Aisyah, 2019). Namun, pada kaum bangsawan bahasa yang dituturkan sedikit berbeda dengan yang dituturkan oleh orang biasa. Penelitian intonasi tuturan emosi ini relatif sedikit. Dari beberapa penelitian yang sudah dilakukan perlu dilakukan penelitian yang khusus tentang persepsi kaum bangsawan Melayu 
terhadap intonasi tuturan emosi. Hal ini menjadi motivasi untuk menemukan fenomena menarik yang berkaitan dengan intonasi tuturan emosi.

Intonasi merupakan sebuah tuturan yang diucapkan penutur (Afriani, 2015). Tuturan tersebut dapat dilihat maknanya pada sebuah konteks. Intonasi merupakan penempatan penekanan dalam pembicaraan merupakan yang sama dengan intonasi yang benar (Tyaningsih, 2016). Mitra tutur dapat memahami makna penutur berdasarkan latar belakang pengetahuan, serta konsep bunyi yang didengarnya, maka dapat menghasilkan sebuah persepsi. Emosi mempunyai peran yang penting dalam komunikasi antar manusia dalam kehidupan sehari-hari. Emosi merupakan sesuatu yang berhubungan dengan kehidupan sehingga dapat mengatur bagaimana memaksimalkan bahasa emosi positif dan meminimalisasi bahasa emosi negatif (Susiati, 2020). Dalam Kamus Besar Bahasa Indonesia (2016) emosi mempunyai arti sebuah luapan perasaan yang berkembang dan surut dalam waktu singkat; sesuai dengan reaksi psikologis (seperti gembira, sedih, haru, perasaan cinta), juga keberanian yang bersifat subjektif.

Metode average digunakan dalam penelitian ini. Metode average sama dengan metode rata-rata yang bergerak, namun nilai terbaru pada deret berkala diberikan beban lebih besar untuk menghitung ramalan (Alfarisi, 2017). Metode Average diberikan bobot yang berbeda pada setiap data historis, dengan anggapan data historis yang paling terakhir lebih memiliki bobot besar dibandingkan dengan data historis yang lama (Gofur \& Dewi, 2015) dipengaruhi sistem fisik dan perfektual (Yulianeu, 2017).

\section{METODE}

Data penelitian berasal dari informan dan responden berupa penutur bahasa Melayu bangsawan dan orang kebanyakan. Informan dalam penelitian ini berjumlah 6 orang yang terdiri atas 3 orang dari kelompok bangsawan dan 3 orang dari kelompok kebanyakan. Mereka berusia antara 20-55 tahun. Alasan memilih 6 orang sebagai informan karena mereka memiliki alat ucap yang baik atau artikulator yang lengkap. Teknik pengambilan informan menggunakan teknik purposive atau berdasarkan tujuan. Penetapan responden ditujukan kepada penutur bahasa Melayu yang memiliki alat ucap yang baik dan artikulasi yang lengkap terjaring sebanyak 40 orang terdiri atas 20 orang kelompok bangsawan dan 20 orang dari kelompok kebanyakan yang keseluruhannya dijadikan sebagai sampel.

Data dikumpulkan dengan cara mengumpulkan tuturan bahasa Melayu (Syam, 2018) dari enam penutur atau informan yang terbagi menjadi kelompok bangsawan dan kelompok orang kebanyakan. Masing-masing penutur mengucapkan tiga tuturan yang terdiri atas tiga aspek emosi yaitu emosi marah, dengan tuturan targetnya Pedeh hati ambe ngeleh kelakuannya tang orang tua! 'Pedih hatiku melihat kelakuannya pada orang tua!' emosi sedih, Pereh kali atine, ia gugor dalam ngelakuka tugasnya 'Sedih sekali hati ini ia gugur dalam melakukan tugasnya' dan emosi senang, Senang bena, amba mendengar kabarnya yo. 'Senang benar mendengar kabar itu'. Tuturan yang direkam atau yang dijaring dalam penelitian ini berupa dialog tak spontan (dipersiapkan) dan dialog kuasi spontan.

Dialog penutur untuk mendapatkan tuturan target emosi marah, Pedeh hati ambe ngeleh kelakuannya tang orang tua adalah sebagai berikut.

A : Sejak tapak dua jari ia dibesarkan dan dipelihara, kinin macam anak durhaka betul ia, tiada begagan tang orang tua, cemana menurutmu? 
Sejak lahir ia dibesarkan dan dipelihara, sekarang seperti anak durhaka betul dia, tidak sopan dengan orang tua, bagaimana pendapatmu?

B : Pedeh hati ambe ngeleh kelakuannya tang orang tua.

Pedih hati saya melihat kelakuannya kepada/dengan orang tua.

Kemudian, dialog penutur untuk mendapatkan tuturan target emosi sedih, Pereh kali ati ne ia gugor dalam ngelakukan tugasnya adalah sebagai berikut.

A : Kalau di keleh masa hayatnya peel dan imannya mendai, tapi so ajalnya tewas begian. Macammana matimu?

Kalau dilihat selama hidupnya tingkah laku dan imannya bagus, tapi sudah ajalnya meninggal begitu. Bagaimana menurutmu?

B : Pereh kali atini, ia gugor dalam ngelakuka tugasnya.

Perih sekali hati ini, ia meninggal dalam melakukan tugasnya.

Dialog penutur untuk mendapatkan tuturan target emosi senang, Senang bena hamba mendengar kabarnya yo adalah sebagai berikut.

A : Nyinya orang sapa yang menyemai ia juga menuai hasil, iyunlah hasilnya jika ia mengabdi, kan begian?

Kata orang siapa yang menyemai dia pula yang menuai hasil, inilah hasilnya jika ia mengabdi, kan begitu?

B : Senang bena, amba mendengar kabarnya yo

Senang sekali saya mendengar kabar itu.

Dialog - dialog di atas menghasilkan kalimat-kalimat atau tuturan-tuturan target yaitu tuturan emosi marah, emosi sedih dan emosi senang yaitu seperti yang tertera di bawah ini.

1. Pedeh hati ambe ngeleh kelakuannya tang orang tua.

[pədeh hati ambə nələh kelakukaňa]

Pedih hati saya melihat kelakuannya kepada orang tua.

2. Pereh kali atini, ia gugor dalam ngelakuka tugasnya.

[pereh kali atine ia gugor dalam nəlakukan tugasňa]

Perih sekali hati ini, ia meninggal dalam melakukan tugasnya.

3. Senang bena, amba mendengar kabarnya yo.

[scnan bena amba mendearn kabarňa jo]

Senang sekali saya mendengar kabar itu.

Metode pengolahan data digunakan untuk menampilkan sebagai temuan penelitian (Darmalaksana, 2020), sehingga mendapatkan informasi yang utuh dan menghasilkan pengetahuan untuk penarikan simpulan. Metode pengumpulan data dengan merekam di stereo cassette-recorder Sony WM-GX410 yang dilengkapi dengan headset mic kemudian dalam proses digitalisasi penelitian ini menggunakan program komputer. Data dianalisis melalui beberapa tahapan (Sidiq dkk, 2019). Tahap yang pertama yaitu proses digitalisasi, pada tahap ini merekam sebuah data menggunakan kaset audio setelah itu dialihkan ke format digital dalam bentuk sound wave- lalu dipilih tuturan yang akan dianalisis. Akhirnya data-data yang sudah terpilih itu akan diberi kode nama. Kode nama untuk tuturan emosi marah pada perekaman pertama memiliki kode 0101, untuk tuturan emosi sedih pada perekaman pertama memiliki kode 0201, dan untuk tuturan emosi senang pada perekaman pertama memiliki kode 0301.

Pada tahapan selanjutnya, melakukan sebuah pengukuran ciri akustik yaitu dengan mengukur frekuensi seta durasi dari setiap tuturan dan merinci hasil pengukuran tersebut ke dalam pangkalan data dan akan menguji persepsi data tersebut dengan menghadirkan responden sebanyak 20 orang dari kalangan 
bangsawan. Untuk uji persepsi ini disusun dalam bentuk kuesioner atau lembar uji persepsi dengan menggunakan tabel yang terdiri atas kolom-kolom yang berisikan nomor, kode, dan data aspek emosi senang. Kemudian pada tahap selanjutnya adalah tahap uji statistik untuk mengetahui signifikan atau tidaknya ciri akustik hasil pengukuran. Pengukuran analisis statistik menggunakan program SPSS versi 17. Eksperimen-eksperimen dilakukan agar dapat membuktikan hipotesis-hipotesis di dalam penelitian ini.

Uji persepsi dilakukan dengan melibatkan 40 orang responden yang terdiri atas 20 kalangan kaum bangsawan. Kaum bangsawan pula terdiri atas 10 orang laki-laki, dan 10 orang perempuan. Adapun modul uji persepsi yang digunakan adalah tipe skala likert, seperti pendapat. Skala Likert digunakan dalam menguji tingkat kesetujuan responden pada suatu pernyataan. Tingkat kesetujuan dibagi atas lima tingkatan yang diberi bobot yaitu (1) Sangat Tidak Setuju (2) Tidak Setuju (3) Cukup Setuju (4) Setuju (5) dan Sangat Setuju, kemudian responden diminta untuk melingkari nomor yang sesuai dengan penilaian responden tersebut.

Skala Likert merupakan skala interval serta perbedaannya antara dua poin pada skala mempunyai nilai yang sama. Dengan pengukuran ini dapat dengan mudah mengukur tingkat emosi senang ketika mengakumulasinya. Pilihan jawaban yang harus responden contreng ketika memilih jawaban untuk emosi senang adalah (1) Sangat Tidak Senang, (2) Tidak Senang, (3) Cukup Senang, (4) Senang, dan (5) Sangat Senang

Hasil dari uji eksperimen pada uji persepsi penelitian ini, data diperoleh dengan Method Average (metode rata - rata) dari data eksperimen pada uji persepsi ini. Dengan cara tersebut dapat dihitung berapa tingkat intonasi tuturan emosi para penutur penutur bahasa Melayu dari kalangan kaum bangsawan yang berdomisili di Tanjung Pura dalam pengucapan intonasi perasaan senang, sedih dan marah. Penelitian ini sangat dibutuhkan bukan hanya untuk mengukur tingkat intonasi (Intonation) para penutur, tetapi nantinya dapat menganalisa jumlah tutur pada intonasi perasaan senang, sedih dan marah para penutur penutur bahasa Melayu dari kalangan kaum bangsawan yang berdomisili di Tanjung Pura. Tanpa menggunakan survey dan Method Average (metode rata - rata), data yang diteliti akan cukup sulit untuk dipastikan apakah data tersebut benar dan lengkap.

\section{HASIL DAN PEMBAHASAN}

Di dalam uji persepsi ini, tuturan-tuturan target yaitu tuturan intonasi perasaan emosi marah, senang dan sedih dari kalangan kaum bangsawan dan orang kebanyakan diukur dengan melihat durasi temporalnya yaitu mengukur masa yang diperlukan pada setiap kali tuturan. Setelah itu tuturan-tuturan itu dideskripsikan dengan melihat alir nada (pitch movement) yang membentuk struktur nada (pitch contours).

\section{Kontur Kalimat atau Tuturan Emosi dari Kalangan Kaum Bangsawan}

Kalimat target tuturan pada intonasi emosi marah, Pedeh ati amba ngeleh kelakuannya tang orang tua. 

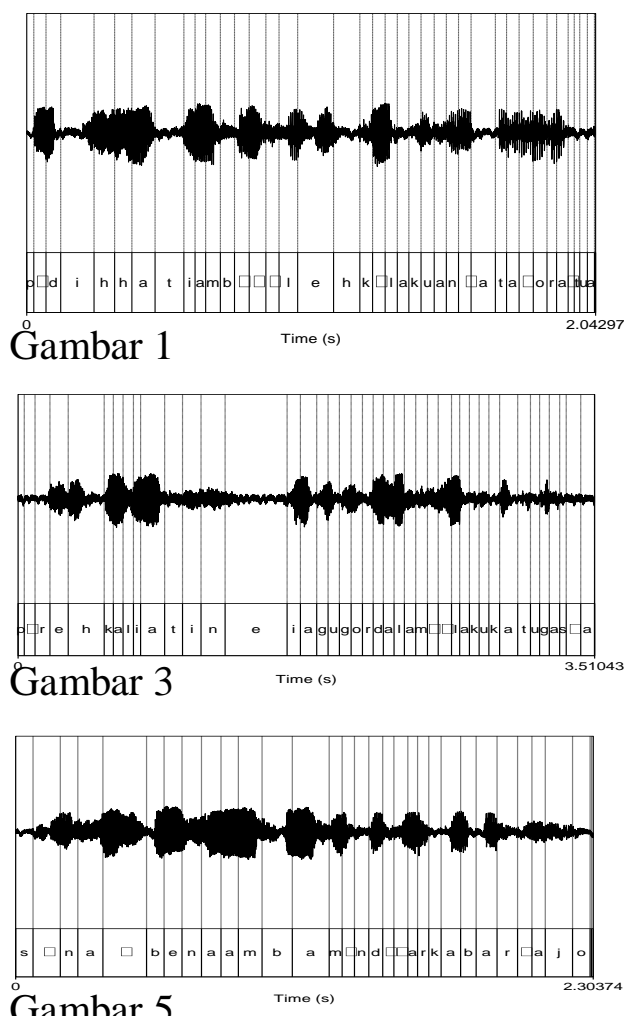

Gambar 5

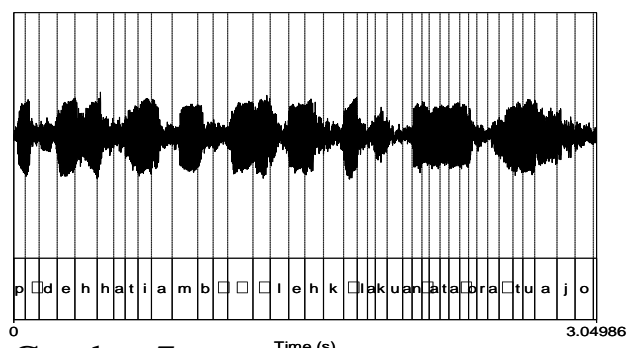

Gambar 7

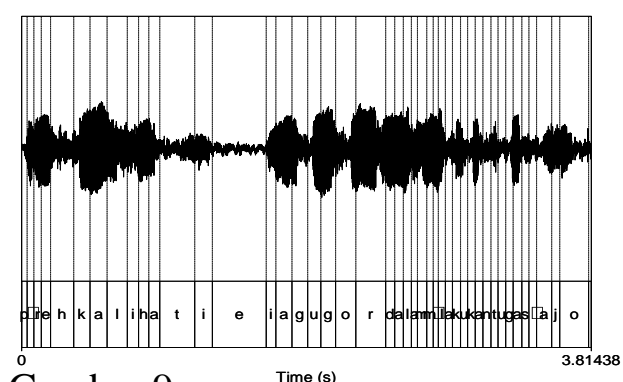

Gambar 9

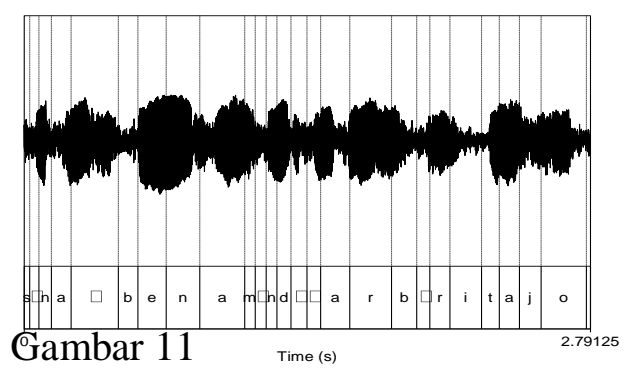

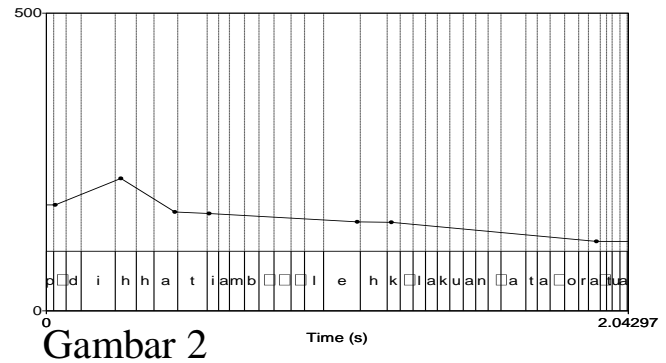
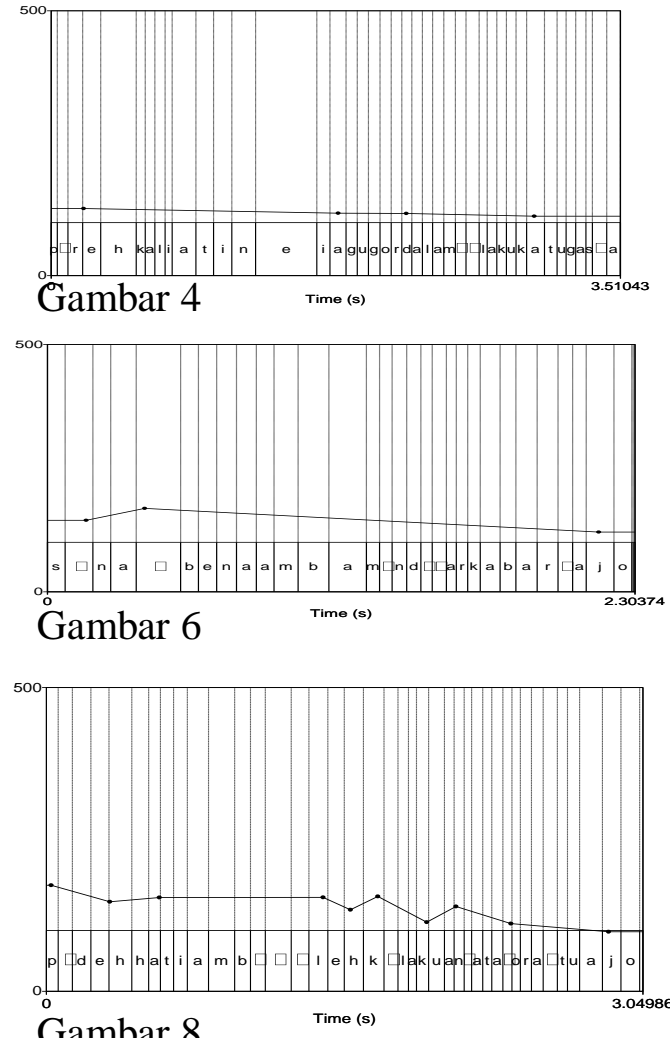

Gambar 8

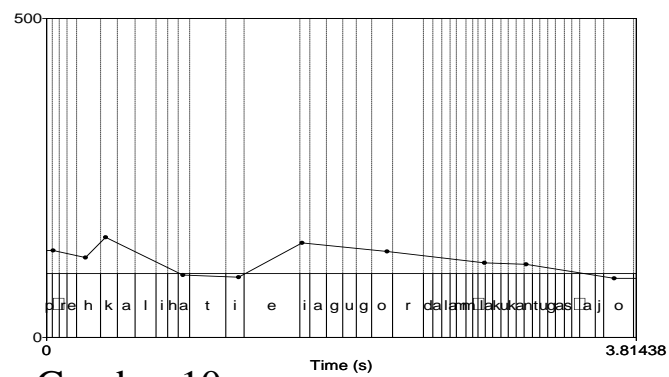

Gambar 10

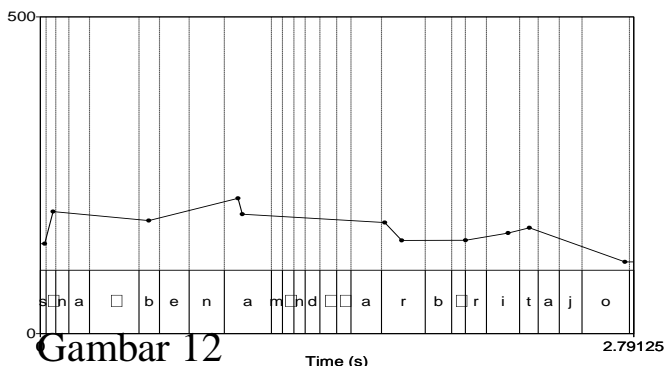


Gambar 1. Sinyal Akustik dan Text Grid tuturan pada intonasi marah, Pedeh hati ambe ngeleh kelakuannya tang orang tua [pedih hati saya melihat kelakuannya kepada orang tua]

Gambar 2. Kontur Nada dan Text Grid tuturan pada intonasi marah, Pedeh ati amba ngeleh kelakuannya tang orang tua [pedih hati saya melihat kelakuannya kepada orang tua]

Gambar 3. Sinyal Akustik dan Text Grid pada tuturan intonasi senang, Senang bena hamba mendengar kabarnya yo [senang sekali saya mendengar kabarnya lah]

Gambar 4. Kontur Nada dan Text Grid tuturan intonasi sedih, Pereh kali ati ne ia gugor dalam ngelakukan tugasnya [perih sekali hati ini ia gugur dalam melakukan tugasnya]

Gambar 5. Sinyal Akustik dan Text Grid tuturan pada intonasi sedih, Pereh kali ati ne ia gugor dalam ngelakukan tugasnya [perih sekali hati ini ia gugur dalam melakukan tugasnya]

Gambar 6. Kontur Nada dan Text Grid tuturan intonasi senang, Senang bena hamba mendengar kabarnya yo [senang sekali saya mendengar kabarnya lah]

Gambar 7. Sinyal Akustik dan Text Grid tuturan intonasi saat marah, Pedeh hati ambe ngeleh kelakuannya tang orang tua yo [pedih hati saya melihat kelakuannya kepada orang tua

Gambar 8. Kontur Nada dan Text Grids tuturan intonasi saat emosi, Pedeh hati ambe ngeleh kelakuannya tang orang tua yo [pedih hati saya melihat kelakuannya kepada orang tua]

Gambar 9. Sinyal Akustik dan Text Grid tuturan intonasi saat sedih, Pereh kali hati e ia gugor dalam ngelakukan tugasnya yo [perih sekali hati saya ia gugur dalam melakukan tugasnya]

Gambar 10. Kontur Nada dan Text Grid tuturan intonasi saat sedih, Pereh kali hati e ia gugor dalam ngelakukan tugasnya yo [perih sekali hati saya ia gugur dalam melakukan tugasnya]

Gambar 11. Sinyal Akustik dan Text Grid tuturan intonasi emosi senang, Senang bena ambe mendengar berita yo [senang sekali saya mendengar beritanya lah]

Gambar 12. Kontur Nada dan Text Grid tuturan intonasi emosi senang, Senang bena ambe mendengar berita yo [senang sekali saya mendengar beritanya lah]

\section{Kontur Kalimat atau Tuturan Emosi dari Kalangan Orang Kebanyakan}

Kalimat target tuturan intonasi emosi marah dari kalangan orang kebanyakan, Pedeh hati ambe ngeleh kelakuannya tang orang tua yo

Frekuensi intonasi emosi marah dari tuturan kalangan kaum bangsawan, Pedeh hati ambe ngeleh kelakuannya tang orang tua [pedih hati saya melihat kelakuannya kepada orang tua].

Tabel 1.

Frekuensi Tuturan Intonasi Emosi Marah dari Kalangan Kaum Bangsawan, Pedeh hati ambe ngeleh kelakuannya tang orang tua

\begin{tabular}{cccccc}
\hline Kontur & $\begin{array}{c}\text { Frek. } \\
\text { Awal }\end{array}$ & $\begin{array}{c}\text { Frek. } \\
\text { Akhir }\end{array}$ & $\begin{array}{c}\text { Frek. } \\
\text { Tinggi }\end{array}$ & $\begin{array}{c}\text { Frek. } \\
\text { Rendah }\end{array}$ & Tempo \\
0101 & 177.0 & 116.7 & 222.5 & 116.7 & 2.04297 \\
\hline
\end{tabular}


Tabel 1 menjelaskan kalimat atau tuturan intonasi emosi marah pada kalangan kaum bangsawan, yaitu Pedeh hati ambe ngeleh kelakuannya tang orang tua memiliki berbagai macam frekuensi yang biasa terdapat di dalam sebuah tuturan yaitu frekuensi awal $177.0 \mathrm{~Hz}$, frekuensi akhir $116.7 \mathrm{~Hz}$, frekuensi tinggi $222.5 \mathrm{~Hz}$, dan frekuensi rendah $116.7 \mathrm{~Hz}$, sedangkan untuk durasi temporal yaitu 2.04297 detik. Frekuensi akhir dan frekuensi rendah terlihat sama yaitu pada $116.7 \mathrm{~Hz}$ pada tuturan tetap menggambarkan frekuensi rendah.

\section{Frekuensi Tuturan Emosi Sedih}

Frekuensi tuturan intonasi emosi sedih dari kalangan kaum bangsawan, Pereh kali ati ne ia gugor dalam ngelakukan tugasnya [perih sekali hati ini ia gugur dalam melakukan tugasnya]

Tabel 2.

Frekuensi Tuturan Intonasi Emosi Sedih dari Kalangan Kaum Bangsawan, Pereh kali ati ne ia gugor dalam ngelakukan tugasnya

\begin{tabular}{cccccc}
\hline Kontur & $\begin{array}{l}\text { Frek. } \\
\text { Awal }\end{array}$ & $\begin{array}{c}\text { Frek. } \\
\text { Akhir }\end{array}$ & $\begin{array}{c}\text { Frek. } \\
\text { Tinggi }\end{array}$ & $\begin{array}{c}\text { Frek. } \\
\text { Rendah }\end{array}$ & Tempo \\
0201 & 128.7 & 112.2 & 126.7 & 112.2 & 3.51043 \\
\hline
\end{tabular}

Berdasarkan hasil tabel 2, kalimat atau tuturan intonasi sedih yang berasal dari kalangan kaum bangsawan, yaitu Pereh kali ati ne ia gugor dalam ngelakukan tugasnya memiliki banyak frekuensi yang biasa terdapat di dalam sebuah tuturan yaitu frekuensi awal $128.7 \mathrm{~Hz}$, frekuensi akhir $112.2 \mathrm{~Hz}$, frekuensi tinggi $126.7 \mathrm{~Hz}$, dan frekuensi rendah $112.7 \mathrm{~Hz}$, sedangkan untuk durasi temporal yaitu 3.51043 detik. Sama dengan tuturan pada saat marah dalam tabel sebelumnya yaitu tabel 4.13, bahwa frekuensi akhir dan frekuensi rendah pada tuturan intonasi emosi sedih dari kalangan kaum bangsawan ini terlihat sama yaitu pada $112.7 \mathrm{~Hz}$ pada akhir tuturan tetap menunjukkan frekuensi rendah.

\section{Frekuensi Tuturan Emosi Senang}

Frekuensi tuturan intonasi emosi senang dari kalangan kaum bangsawan, Senang bena hamba mendengar kabarnya yo [senang sekali saya mendengar kabarnya lah].

Tabel 3.

Frekuensi Tuturan Intonasi Emosi Senang dari Kalangan Kaum Bangsawan, Senang bena hamba mendengar kabarnya yo

\begin{tabular}{llcccc}
\hline Kontur & Frek. & $\begin{array}{c}\text { Frek. } \\
\text { Akhir }\end{array}$ & $\begin{array}{c}\text { Frek. } \\
\text { Tinggi }\end{array}$ & $\begin{array}{c}\text { Frek. } \\
\text { Rendah }\end{array}$ & Tempo \\
0301 & 144.4 & 120.7 & 168.7 & 120.7 & 2.30374 \\
\hline
\end{tabular}

Berdasarkan tabel 3, kalimat atau tuturan intonasi pada saat senang dari kalangan kaum bangsawan, yaitu Senang bena hamba mendengar kabarnya yo terdapat macam-macam frekuensi yang biasa terdapat di dalam sebuah tuturan yaitu frekuensi awal $144.4 \mathrm{~Hz}$, frekuensi akhir $120.7 \mathrm{~Hz}$, frekuensi tinggi $168.7 \mathrm{~Hz}$, dan frekuensi rendah $120.7 \mathrm{~Hz}$, sedangkan untuk durasi temporal yaitu 2.30374 detik. Sama juga dengan tuturan emosi marah dan emosi sedih yang berarti bahwa frekuensi 
akhir dan frekuensi rendah pada tuturan intonasi emosi senang dari kalangan kaum bangsawan ini terlihat sama yaitu pada $120.7 \mathrm{~Hz}$ dan menunjukkan frekuensi rendah.

\section{Frekuensi Tuturan Emosi Kalangan Kaum Kebanyakan}

Frekuensi tuturan intonasi emosi marah dari kalangan orang kebanyakan, Pedeh hati ambe ngeleh kelakuannya tang orang tua yo [pedih hati saya melihat kelakuannya kepada orang tua]

Tabel 4.

Frekuensi Tuturan Intonasi Emosi Marah, Pedeh hati ambe ngeleh kelakuannya tang orang tua yo

\begin{tabular}{cccccc}
\hline Kontur & $\begin{array}{c}\text { Frek. } \\
\text { Awal }\end{array}$ & $\begin{array}{c}\text { Frek. } \\
\text { Akhir }\end{array}$ & $\begin{array}{c}\text { Frek. } \\
\text { Tinggi }\end{array}$ & $\begin{array}{c}\text { Frek. } \\
\text { Rendah }\end{array}$ & Tempo \\
0102 & 180.7 & 98.1 & 180.7 & 98.1 & 3.04986 \\
\hline
\end{tabular}

Berdasarkan tabel 4, kalimat atau tuturan intonasi pada saat marah yang berasal dari orang kebanyakan, yaitu Pedeh hati ambe ngeleh kelakuannya tang orang tua yo juga terdapat berbagai macam frekuensi yang biasa terdapat di dalam sebuah tuturan yaitu frekuensi awal $180.7 \mathrm{~Hz}$, frekuensi akhir $98.1 \mathrm{~Hz}$, frekuensi tinggi 180.7 $\mathrm{Hz}$, dan frekuensi rendah $98.1 \mathrm{~Hz}$, sedangkan untuk durasi temporal yaitu 3.04986 detik. Sama dengan tuturan pada saat marah, emosi sedih dan emosi senang pada kalangan kaum bangsawan yang berarti bahwa frekuensi akhir dan frekuensi rendah menunjukkan frekuensi yang sama pada masing-masing emosi. Tuturan intonasi pada saat marah dari kalangan orang kebanyakan ini juga terlihat sama yaitu pada $98.1 \mathrm{~Hz}$.

\section{Frekuensi Tuturan Emosi Sedih}

Frekuensi tuturan intonasi emosi sedih dari kalangan orang kebanyakan, Pereh kali hati e ia gugor dalam ngelakukan tugasnya yo [perih sekali hati saya ia gugur dalam melakukan tugasnya]

Tabel 5

Frekuensi Tuturan Intonasi Emosi Sedih, Pereh kali hati e ia gugor dalam ngelakukan tugasnya yo

\begin{tabular}{|c|c|c|c|c|c|}
\hline Kontur & $\begin{array}{l}\text { Frek. } \\
\text { Awal }\end{array}$ & $\begin{array}{l}\text { Frek. } \\
\text { Akhir }\end{array}$ & $\begin{array}{l}\text { Frek. } \\
\text { Tinggi }\end{array}$ & $\begin{array}{c}\text { Frek. } \\
\text { Rendah }\end{array}$ & Tempo \\
\hline 0202 & 137.9 & 92.7 & 156.9 & 92.7 & 3.81438 \\
\hline
\end{tabular}

Tabel tersebut menunjukan kalimat atau tuturan intonasi pada saat sedih yang berasal dari orang kebanyakan, yaitu Pereh kali hati e ia gugor dalam ngelakukan tugasnya yo juga memiliki berbagai macam frekuensi yang biasa terdapat pada sebuah tuturan yaitu frekuensi awal $137.9 \mathrm{~Hz}$, frekuensi akhir $92.7 \mathrm{~Hz}$, frekuensi tinggi $156.9 \mathrm{~Hz}$, dan frekuensi rendah $92.7 \mathrm{~Hz}$, sedangkan untuk durasi temporal yaitu 3.81438 detik. Sama dengan tuturan emosi marah, senang, dan sedih pada bangsawan dan marah pada kalangan orang kebanyakan bahwa frekuensi akhir dan frekuensi rendah menunjukkan frekuensi yang sama pada masing-masing emosi. Tuturan intonasi pada saat sedih yang berasal dari orang kebanyakan juga terlihat sama yaitu pada $92.7 \mathrm{~Hz}$. 
Indonesian Language Education and Literature

e-ISSN: 2502-2261

http://www.syekhnurjati.ac.id/jurnal/index.php/jeill/

Vol. 6, No. 2, Juli 2021, 220- 235

\section{Frekuensi Tuturan Emosi Senang}

Frekuensi tuturan intonasi senang dari kalangan kebanyakan, Senang bena ambe mendengar berita yo [senang sekali saya mendengar beritanya lah]

Tabel 6.

Frekuensi Tuturan Intonasi Emosi Senang, Senang bena ambe mendengar berita yo

\begin{tabular}{cccccc}
\hline Kontur & $\begin{array}{c}\text { Frek. } \\
\text { Awal }\end{array}$ & $\begin{array}{c}\text { Frek. } \\
\text { Akhir }\end{array}$ & $\begin{array}{c}\text { Frek. } \\
\text { Tinggi }\end{array}$ & $\begin{array}{c}\text { Frek. } \\
\text { Rendah }\end{array}$ & Tempo \\
0302 & 144.4 & 113.4 & 213.7 & 113.4 & 2.79125 \\
\hline
\end{tabular}

Berdasarkan tabel 6, kalimat pada intonasi senang dari kalangan orang kebanyakan, yaitu Senang bena ambe mendengar berita yo juga ada berbagai macam frekuensi yang biasa terdapat sebuah tuturan yaitu frekuensi awal $144.4 \mathrm{~Hz}$, frekuensi akhir $113.4 \mathrm{~Hz}$, frekuensi tinggi $213.7 \mathrm{~Hz}$, dan frekuensi rendah $113.4 \mathrm{~Hz}$, sedangkan untuk durasi temporal yaitu 2.79125 detik. Sama dengan tuturan emosi pada kaum bangsawan dan tuturan marah dan sedih pada orang kebanyakan dengan frekuensi akhir dan frekuensi rendah menunjukkan frekuensi yang sama pada masing-masing emosi. Pada tuturan intonasi emosi sedih dari kalangan orang kebanyakan ini juga terlihat sama yaitu pada $113.4 \mathrm{~Hz}$.

Hasil Uji Persepsi

Berikut hasil uji persepsi berdasarkan data yang sudah dikumpulkan,

Tabel 7.

Data Hasil Uji Persepsi Emosi Marah

\begin{tabular}{|c|c|c|c|c|c|c|c|c|c|c|c|c|c|}
\hline Kontur & $\begin{array}{c}\text { Kode } \\
\text { Stimulus }\end{array}$ & & & Skor & & & Total & & & Nilai & & & $\begin{array}{l}\text { Total } \\
\text { Nilai }\end{array}$ \\
\hline & & STM & $\mathrm{TM}$ & $\mathrm{CM}$ & $\mathrm{M}$ & SM & & STM & $\mathrm{TM}$ & $\mathrm{CM}$ & $\mathrm{M}$ & SM & \\
\hline Emosi & $\begin{array}{c}\mathrm{AO} \\
\mathrm{AOO}\end{array}$ & $\begin{array}{l}3 \\
1\end{array}$ & $\begin{array}{l}6 \\
1\end{array}$ & $\begin{array}{c}4 \\
10 \\
\end{array}$ & $\begin{array}{l}26 \\
27\end{array}$ & $\begin{array}{l}1 \\
1\end{array}$ & $\begin{array}{l}40 \\
40 \\
\end{array}$ & $\begin{array}{l}3 \\
1 \\
\end{array}$ & $\begin{array}{c}12 \\
2 \\
\end{array}$ & $\begin{array}{l}12 \\
30\end{array}$ & $\begin{array}{l}104 \\
108 \\
\end{array}$ & $\begin{array}{l}5 \\
5 \\
\end{array}$ & $\begin{array}{l}136 \\
146 \\
\end{array}$ \\
\hline
\end{tabular}

Dari tabel 7 terlihat bahwa ada beberapa persepsi yang berbeda ketika uji persepsi terhadap emosi marah yang dilakukan pada 40 responden terdiri atas kaum bangsawan dan kelompok orang kebanyakan. Uji statistik paired T Test SPSS versi 17 untuk diketahui berapa signifikansi perbedaan antara stimulus A0 dengan dan A00 dengan hasilnya menunjukkan signifikansi dengan probabilitas (p) 0,086 (signifikan).

Tabel 8.

Analisis Data Uji Persepsi Emosi Marah

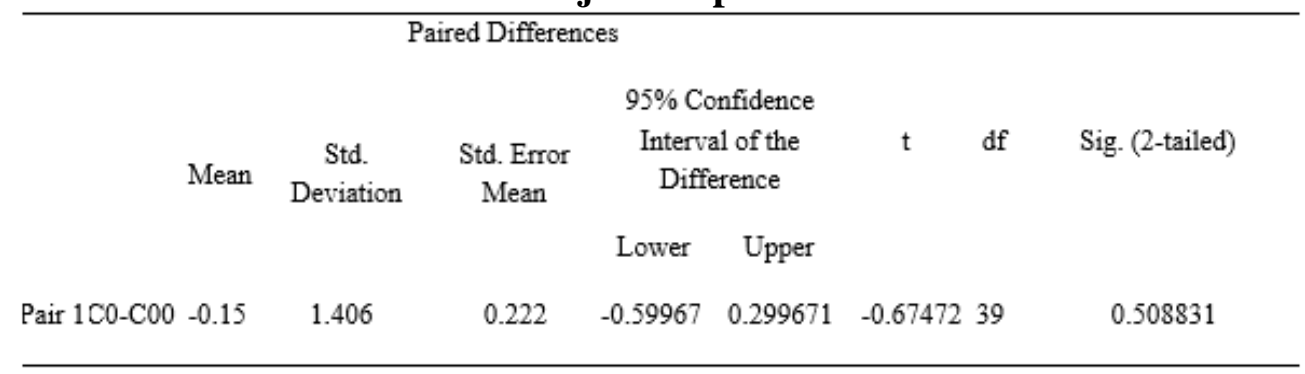


Berdasarkan tabel, kontur asli tuturan emosi marah yang dituturkan kalangan kaum bangsawan yang dipersepsikan responden menunjukkan perbedaan yang tidak signifikan. Kontur nada asli tuturan emosi marah yang dituturkan oleh kalangan bangsawan memiliki bentuk yang sama yaitu kontur yang menurun (deklinasi). Tuturan marah oleh kaum bangsawan lebih rendah dan ada perbedaan durasi.

Tabel 9.

Data Hasil Uji Persepsi Emosi Sedih

\begin{tabular}{|c|c|c|c|c|c|c|c|c|c|c|c|c|c|}
\hline \multirow{3}{*}{ Kontur } & \multirow{3}{*}{$\begin{array}{c}\text { Kode } \\
\text { Stimulus }\end{array}$} & \multicolumn{11}{|c|}{ Total } & \multirow{3}{*}{$\begin{array}{l}\text { Total } \\
\text { Nilai }\end{array}$} \\
\hline & & & & Skor & & & Responden & & & Nilai & & & \\
\hline & & STS & TS & $\mathrm{CS}$ & $\mathrm{S}$ & SS & & STS & TS & $\begin{array}{l}\mathrm{C} \\
\mathrm{S}\end{array}$ & $\mathrm{S}$ & SS & \\
\hline Emosi & $\begin{array}{l}\text { B0 } \\
\text { B00 }\end{array}$ & $\begin{array}{l}2 \\
2\end{array}$ & $\begin{array}{l}2 \\
5\end{array}$ & $\begin{array}{c}11 \\
6\end{array}$ & $\begin{array}{l}22 \\
25\end{array}$ & $\begin{array}{l}3 \\
2\end{array}$ & $\begin{array}{l}40 \\
40\end{array}$ & $\begin{array}{l}2 \\
2\end{array}$ & $\begin{array}{c}4 \\
10\end{array}$ & $\begin{array}{l}33 \\
18\end{array}$ & $\begin{array}{c}88 \\
100\end{array}$ & $\begin{array}{l}15 \\
10\end{array}$ & $\begin{array}{l}142 \\
140\end{array}$ \\
\hline
\end{tabular}

Dari tabel 9 menunjukkan bahwa persepsi yang beragam didapati ketika uji persepsi terhadap emosi sedih dilakukan terhadap 40 responden yang terdiri atas kalangan bangsawan. Uji statistik paired T Test SPSS versi 17 untuk mengetahui signifikansi perbedaan antara stimulus B0 dengan stimulus B00 dengan yang hasilnya menunjukkan signifikansi dengan probabilitas (p) 0,00 (signifikan).

Tabel 10.

Analisis Data Hasil Uji Persepsi Emosi Sedih

Paired Differences

\begin{tabular}{ccccccccc} 
& Mean & Std. Deviation & $\begin{array}{c}\text { Std. Error } \\
\text { Mean }\end{array}$ & $\begin{array}{c}95 \% \text { Confidence } \\
\text { Interval of the } \\
\text { Difference }\end{array}$ & T & df & $\begin{array}{c}\text { Sig. (2- } \\
\text { tailed) }\end{array}$ \\
Pair 1 B0-B00 & 0.8 & 1.135797 & 0.179743 & 0.436435 & 1.16356536 & 4.450789 & 39 & 0.00 \\
\hline
\end{tabular}

Dari tabel 10 di atas, kontur nada asli tuturan emosi yang dituturkan oleh kaum bangsawan yang dipersepsikan, hasil responden menunjukkan ada perbedaan yang cukup signifikan. Kontur nada asli tuturan sedih yang dituturkan oleh bangsawan memiliki bentuk yang berbeda yaitu kontur yang relatif dasar (inklanasi). Tuturan emosi sedih dari kalangan kaum bangsawan lebih rendah dan terdapat perbedaan durasi pada saat pengucapan

Tabel 11.

Data Hasil Uji Persepsi Emosi Senang

\begin{tabular}{|c|c|c|c|c|c|c|c|c|c|c|c|c|c|}
\hline \multirow{3}{*}{ Kontur } & Kode & \multicolumn{11}{|c|}{ Total } & \multirow{2}{*}{$\begin{array}{l}\text { Total } \\
\text { Nilai }\end{array}$} \\
\hline & Stimulus & & & Skor & & & Responden & & & Nilai & & & \\
\hline & & STS & TS & CS & $\mathrm{S}$ & SS & & STS & TS & CS & S & SS & \\
\hline Emosi & $\mathrm{C} 0$ & 2 & 4 & 12 & 11 & 11 & 40 & 2 & 8 & 36 & 44 & 55 & 145 \\
\hline & $\mathrm{C} 00$ & 1 & 2 & 6 & 27 & 4 & 40 & 1 & 4 & 18 & 108 & 20 & 151 \\
\hline
\end{tabular}


Dari tabel 11 menunjukkan bahwa persepsi yang beragam didapati ketika uji persepsi terhadap emosi senang dilakukan terhadap 40 responden yang terdiri atas kalangan kaum bangsawan. Uji statistik paired $T$ Test SPSS versi 17 untuk mengetahui signifikansi perbedaan antara stimulus C0 dengan stimulus C00 pada taraf $\alpha=0,05$ dan df $n-1$ hasil menunjukkan bahwa $t$ hitung $(0,6747)<t$ tabel $(2,02)$ dengan probabilitas (p) 0,503 maka perbedaan stimulus $\mathrm{CO}$ dengan stimulus COO tidak signifikan.

Tabel 12.

Data Hasil Uji Persepsi Emosi Senang

Paired Differences

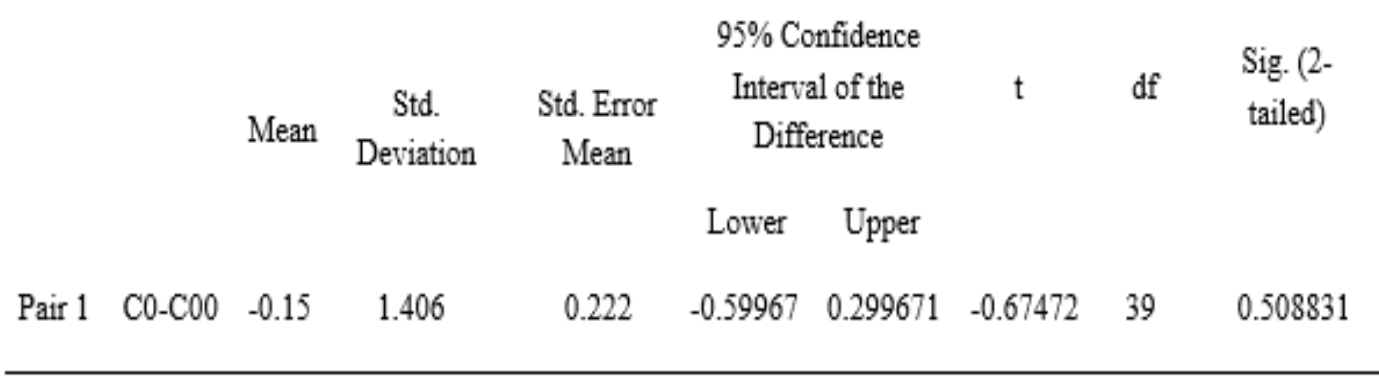

Dari tabel 12, kontur asli tuturan emosi senang yang dituturkan oleh penutur kalangan kaum bangsawan yang dipersepsikan responden tidak menunjukkan perbedaan persepsi emosi senang yang signifikan. Kontur nada asli tuturan emosi senang yang dituturkan oleh penutur kalangan kaum bangsawan kebanyakan memiliki bentuk yang sama yaitu kontur yang naik dan menurun (deklinasi) tetapi dengan perbedaan frekuensi yang signifikan. Tuturan emosi senang dari kalangan kaum bangsawan lebih rendah dan terdapat perbedaan durasi pada saat pengucapan.

Gambar 13. Diagram Hasil uji persepsi intonasi Emosi Marah. Berdasarkan gambar 13, menunjukkan intonasi asli tuturan emosi marah kaum bangsawan. Gambar tersebut menunjukkan suara asli informan dari kalangan kaum bangsawan yang diuji persepsikan kepada 40 responden kalangan kaum bangsawan, 16 orang (40\%) diantara responden memberikan persepsi marah.

Gambar 14. Diagram Hasil uji persepsi intonasi Emosi Marah Intonasi +7 . Berdasarkan gambar 14, menunjukkan intonasi $0101 \mathrm{~B}(\mathrm{~F})+7$ st. Dimana setelah frekuensi suara dinaikkan 7 st $(0101 \mathrm{~B}(\mathrm{f})+7)$ sebanyak $12(30 \%)$ responden memberikan persepsi sangat marah, sedangkan $7(17,5)$ responden memberikan persepsi cukup marah, 1 (2,5\%) responden memberikan persepsi sangat marah.

Gambar 15. Diagram Hasil uji persepsi intonasi Emosi Marah - 6. Berdasarkan gambar 15 menunjukkan intonasi 0101C (F) - 6 st tuturan emosi (marah) kaum bangsawan. Dimana data di atas setelah frekuensi suara diturunkan 6 st (0101 C (F) -6) sebanyak 14 (35\%) orang responden memberikan persepsi tidak marah.

Gambar 16. Diagram Hasil uji persepsi Intonasi Emosi Sedih. Berdasarkan gambar 16 menunjukkan intonasi 0201A Asli tuturan emosi (sedih) kaum bangsawan yang menunjukkan hampir seluruh responden menyatakan persepsi emosi sedih. 
Persepsi Responden Kaum Bangsawan Terhadap Intonasi Tuturan Emosi Marah, Sedih, dan Senang

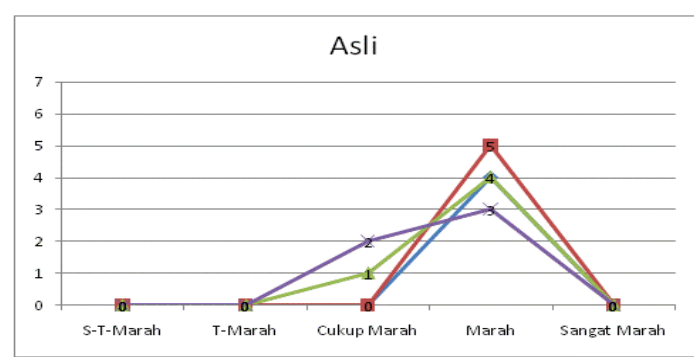

Gambar 13

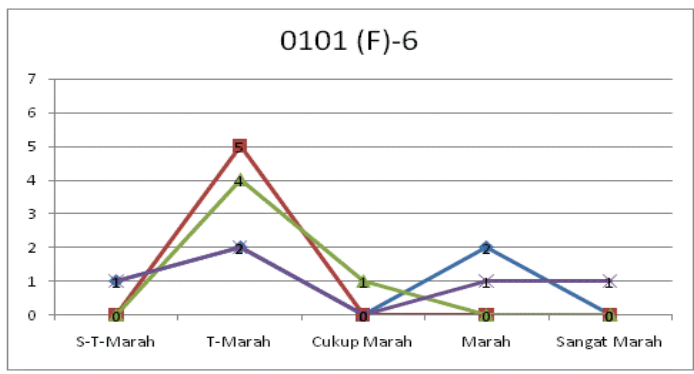

Gambar 15

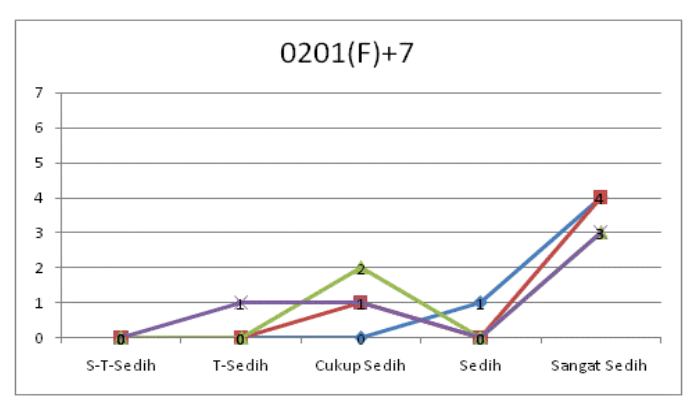

Gambar 17

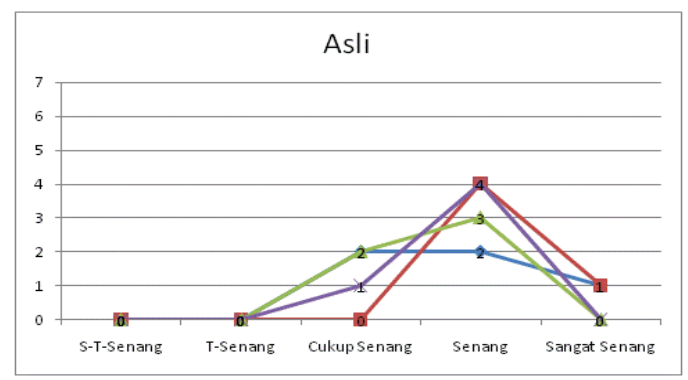

Gambar 19

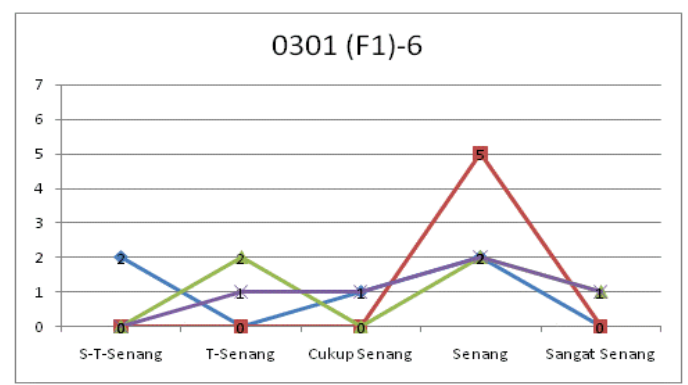

Gambar 21

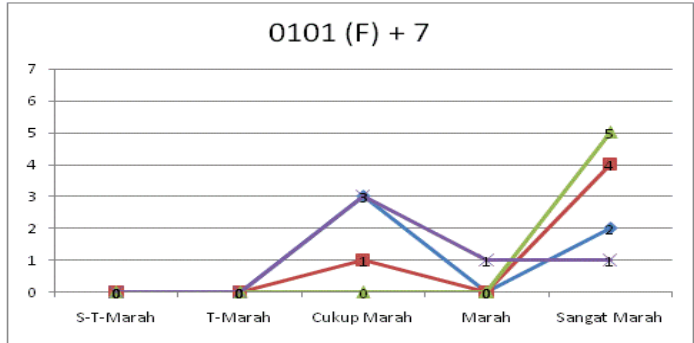

Gambar 14

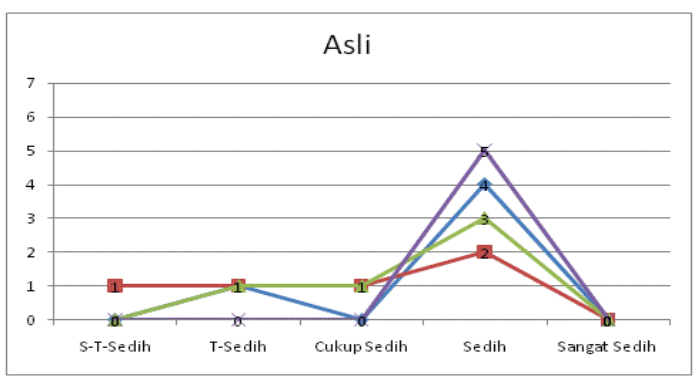

Gambar 16

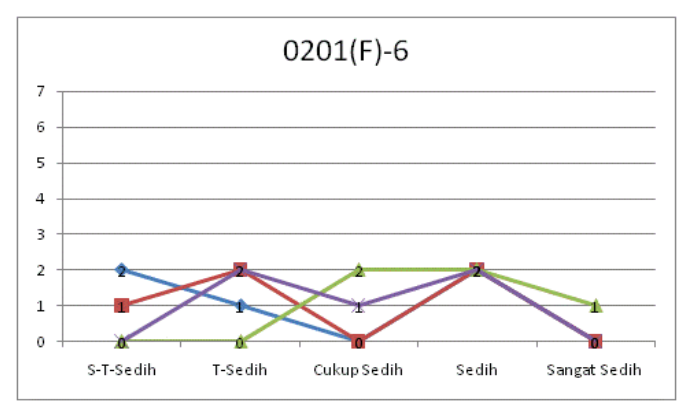

Gambar 18

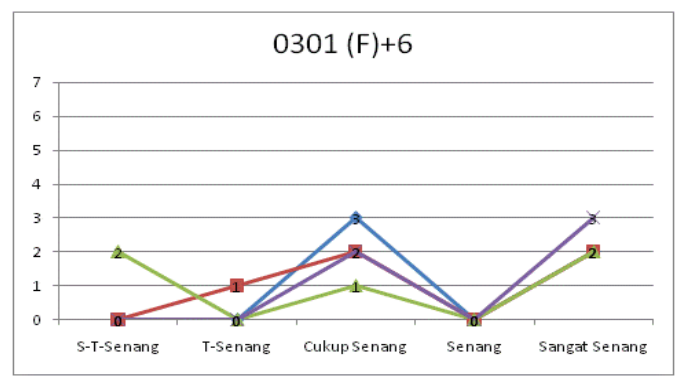

Gambar 20 
Gambar 17. Diagram Hasil uji persepsi Intonasi Emosi Sedih +7 . Berdasarkan gambar 17 menunjukkan Intonasi 0210D (F) + 7 st tuturan emosi (sedih) kaum bangsawan yang dimana ketika frekuensi suara dinaikkan 7 st $(0210 \mathrm{D}(\mathrm{F})+7)$ nilai tertinggi terletak pada tingkat emosi sangat sedih dimana sebanyak 14 (35\%) responden memberikan jawaban sangat sedih.

Gambar 18. Diagram Hasil uji persepsi Intonasi Emosi Sedih - 6. Berdasarkan gambar 18 menunjukkan intonasi 0210F (F) - 6 st tuturan Emosi (sedih)Kaum Bangsawan yang dimana setelah frekuensi suara diturunkan 6 st (0210 F (F) -6) terjadi varian penyebaran. Masing-masing tingkat emosi terwakili. Tingkat emosi yang tertinggi terjadi pada emosi sedih, sebanyak 8 (20\%) responden memberikan jawaban sedih.

Gambar 19. Diagram Hasil uji persepsi Intonasi Emosi Senang. Berdasarkan gambar 19 menunjukkan intonasi 0310A asli tuturan emosi senang kaum bangsawan yang dimana pada kalimat senang dengan intonasi asli yang diperdengarkan hampir seluruh responden menunjukkan persepsi dengan emosi senang.

Gambar 20. Diagram Hasil uji persepsi Intonasi Emosi Senang + 7. Berdasarkan gambar 20 menunjukkan intonasi 0301B $(\mathrm{F})+6$ st tuturan emosi senang kaum bangsawan yang dimana setelah frekuensi suara dinaikkan 6 st (0301 B (F) + 6) dan diperdengarkan, terlihat tanggapan kelompok responden masuk kepada kategori sangat senang. Pada tingkat ini menunjukkan juga bahwa persepsi responden berada pada tingkat emosi sangat senang. Sebanyak 9 (22,5\%) responden memberikan persepsi sangat senang, sedangkan $2(5 \%)$ responden memberikan persepsi sangat tidak senang.

Gambar 21. Diagram Hasil uji persepsi Intonasi Emosi Senang - 6. Berdasarkan gambar 21 menunjukkan intonasi 0310H (F1) - 6 tuturan emosi senang kaum bangsawan yang dimana setelah frekuensi intonasi diturunkan 6 st $(0310 \mathrm{G}(\mathrm{F})-6)$, sebanyak $8(20 \%)$ responden memberikan persepsi senang, $8(20 \%)$ responden memberikan persepsi tidak senang, sedangkan $2(5 \%)$ responden memberikan persepsi sangat senang.

\section{SIMPULAN}

Berdasarkan analisis 40 responden, kontur nada asli dan struktur melodi tuturan: 1) emosi marah menunjukkan perbedaan yang tidak signifikan, 2) emosi sedih menunjukkan perbedaan yang signifikan, dan 3) emosi senang menunjukkan perbedaan persepsi yang signifikan. Kontur nada asli dan struktur melodik tuturan emosi sedih menunjukkan perbedaan yang signifikan. Kaum bangsawan memiliki bentuk kontur yang relatif datar (inklanasi) dan intonasi tuturan emosi sedih dari kalangan kaum bangsawan lebih rendah dan terdapat perbedaan durasi pada saat pengucapan. Persepsi responden pada kalangan kaum bangsawan terhadap intonasi tuturan emosi marah kalangan kaum bangsawan adalah apabila frekuensinya dinaikkan, persepsi responden adalah marah. Jika frekuensi diturunkan, persepsi responden adalah tidak marah. Lalu responden memberikan respon pada kalangan kaum bangsawan terhadap intonasi tuturan emosi sedih kalangan kaum bangsawan adalah apabila frekuensinya dinaikkan, persepsi responden adalah sedih.

\section{DAFTAR PUSTAKA}

Alfarisi, S. (2017). Sistem Prediksi Penjualan Gamis Toko QITAZ Menggunakan Metode Single Exponential Smoothing. JABE: Journal of Applied Business and Economic, 4(1), 80-95. 
Afriani, S. H. (2015). Analisis Uji Persepsi: Intonasi Kalimat Perintah Bahasa Indonesia oleh Penutur Bahasa Jepang. Tamaddun: Jurnal Kebudayaan dan Sastra Islam, 15(1), 149-170.

Aisyah, A. S. (2019). Eksistensi Kaum Bangsawan dalam Birokrasi di Kabupaten Bone. Jurnal Kajian Sosial dan Budaya: Tebar Science, 3(2), 83-91.

Astuti, W. D. (2018). Persepsi Tindak Tutur Ekspresif Marah Masyarakat Suku Betawi di Kecamatan Beji, Depok: Kajian Sosio-Pragmatik. Widyaparwa, 46(1), 30-48.

Cahyono, B. E. H. (2016). Kalimat Inversi dalam Bahasa Indonesia. Indonesian Language Education and Literature, 1(2), 173-193.

Darmalaksana, W. (2020). Metode Penelitian Kualitatif Studi Pustaka dan Studi Lapangan. Pre-Print Digital Library UIN Sunan Gunung Djati Bandung.

Defren, S., Wesseling, P. B., Allen, S., Shakuf, V., Ben-David, B., \& Lachmann, T. (2018). Emotional Speech Perception: A set of semantically validated German neutral and emotionally affective sentences. In Proceedings of the International Conference on Speech Prosody 2018, 714-718).

Gofur, A. A., \& Widianti, U. D. (2015). "Sistem Peramalan untuk Pengadaan Material Unit Injection di PT. XYZ." Komputa: Jurnal Ilmiah Komputer dan Informatika, 2(2), 13-18.

Ganie, R. (2014). Intonasi Kesantunan Tindak Tutur Direktif Bahasa Aceh, Dialek Aceh Timur: Kajian Fonetik Eksperimental. Reposiroty Universitas Sumatera Utara.

Jamil, K., \& Silvana, T. (2017). Durasi Akustik Pembelajar Bahasa Arab di Medan. RETORIKA: Jurnal Ilmu Bahasa, 3(1), 62-69.

Kementerian Pendidikan dan Kebudayaan. (2016). Kamus Besar Bahasa Indonesia. Jakarta: Balai Pustaka.

Mohamed, Y., Hoque, M., Ismail, T. H. S. B., Ibrahim, M. H., Saad, N. M., \& Zaidi, N. N. M. (2021). Relationship Between Phonology, Phonetics, and Tajweed: A Literature Review. In 4th International Conference on Sustainable Innovation 2020-Social, Humanity, and Education (ICoSIHESS 2020), 407-411. Atlantis Press.

Nasir, Z. M., \& Hamzah, Z. A. Z. (2014). Sikap dan Motivasi Pelajar Terhadap Pembelajaran Bahasa Melayu. Procedia-Social and Behavioral Sciences, 134, 408-415.

Ningsih, D. P., \& Sukidjo. (2014). Pola Asuh Kaum Bangsawan Lalu-Baiq dalam Membentuk Karakter Anak di Desa Padamara Lombok Timur. Harmoni Sosial: Jurnal Pendidikan IPS, 1(2), 119-129.

Oktavia, W. (2018). Penamaan bunyi segmental dan suprasegmental pada pedagang keliling. Jurnal Bahasa Lingua Scientia, 10(1), 1-16.

Poegoeh, D. P., \& Hamidah, H. (2016). Peran Dukungan Sosial dan Regulasi Emosi Terhadap Resiliensi Keluarga Penderita Skizofrenia. INSAN Jurnal Psikologi dan Kesehatan Mental, 1(1), 12-21.

Prasetyo, A. H. (2018). Tindak Tutur Ekspresif dalam Film "Kartini” Karya Hanung Bramantyo: Kajian Sosiopragmatik. BAPALA, 5(2), 1-10.

Prihartono, W. (2018). Identifikasi Tuturan Latah: Pendekatan Fonetik Akustik. Madah, 8(2), 161-176.

Rois, H. (2020). Digitalisasi Tuturan Psikogenik Latah (Kajian Fonetik Akustik). Belajar Bahasa: Jurnal Ilmiah Program Studi Pendidikan Bahasa dan Sastra Indonesia, 5(1), 39-50. 
Sidiq, U., Choiri, M. M., \& Mujahidin, A. (2019). Metode Penelitian Kualitatif di Bidang Pendidikan. Ponorogo: CV Nata.

Senen, M. D. (2017). Kontribusi Ilmu Fonetik dalam Studi Bahasa Arab. Tamaddun: Jurnal Kebudayaan dan Sastra Islam, 17(1), 37-58.

Susiati, S. (2020). Fenomena Tuturan Emosi Verbal Bahasa Indonesia Suku Bajo Sampela, June 14. https://doi.org/10.31219/osf.io/vbeh7

Syam, E. (2018). Rancang Bangun Sistem Informasi Manajemen Data Mahasiswa dan Dosen Terintegrasi. IT Journal Research and Development, 2(2), 45-51.

Tyaningsih, R. Y. (2016). Keterampilan Komunikasi Lisan Calon Guru Matematika Pada Mata Kuliah Proses Belajar Mengajar (MK PBM). Jurnal Math Educator Nusantara: Wahana Publikasi Karya Tulis Ilmiah di Bidang Pendidikan Matematika, 2(1), 55-66.

Yulianeu, A. (2017). Aplikasi Perhitungan Stok Barang di WASERDA Koperasi Unit Desa Minarasa Batukaras dengan Menggunakan Metode Average. JUTEKIN (Jurnal Teknik Informatika), 1(2), 53-62. 